\title{
ReC $\sqrt{\Delta} \sqrt{\square}$
}

\section{Volume 21 Part 3 September 2009}

\section{CONTENTS}

Editorial

June Thompson

\section{Regular papers}

Developing conversational competence through language awareness and multimodality:

the use of DVDs

María Moreno Jaén and Carmen Pérez Basanta

Speed bumps for authentic listening material

Marty Meinardi

The effect of using an online-based course on the learning of grammar inductively

and deductively

Ali Farhan AbuSeileek

Discussing course literature online: analysis of macro speech acts in an asynchronous

computer conference

Riitta Kosunen

\section{Selected paper from EUROCALL 2008}

New competencies in a new era? Examining the impact of a teacher training project

Melinda Dooly

Response to book review

EUROCALL Resources

Printed in the United Kingdom by the University Press, Cambridge

\section{Cambridge Journals Online}

For further information about this journal please go to the journal website at: journals.cambridge.org/rec
Mixed Sources
$\begin{aligned} & \text { Product group from well-managed } \\ & \text { forests and other controlled sources } \\ & \text { www.fsc. org Cert no. SA-COC-1527 } \\ & \text { @1996 Forest Stewardship Council }\end{aligned}$ 


\title{
Notes for Contributors
}

\begin{abstract}
Aims and Scope
$\operatorname{ReCALL}$, the journal of the European Association for Computer Assisted Language Learning (EUROCALL), seeks to fulfil the stated aims of EUROCALL as a whole, which are to advance education by: (a) promoting the use of foreign languages within Europe; (b) providing a European focus for the promulgation of innovative research, development and practice in the area of computer-assisted language learning and technology enhanced language learning in education and training; and (c) enhancing the quality, diffusion and cost-effectiveness of relevant language learning materials. Typical subjects for submissions include theoretical debate on language learning strategies and their influence on courseware design, practical applications at developmental stage, evaluative studies of courseware use in the teaching and learning process, assessment of the potential of technological advances in the delivery of language learning materials, exploitation of on-line information systems, and discussions of policy and strategy at institutional and discipline levels. Survey papers are welcome provided that they are timely, up-to-date and well-structured. All contributions are peer reviewed.
\end{abstract}

\section{Guidelines for contributors, including the criteria for reviewers, is at http://www.eurocall-languages.org/recall/contribguide.html}

\section{General}

1. Submission of a paper to ReCALL is held to imply that it represents an original contribution not previously published and that it is not being considered elsewhere.

2. The language of ReCALL is normally English. However, papers in other European languages, with an abstract in English, are welcome.

3. Authors should be aware that editorial licence may be taken to improve the readability of an article.

4. Papers should normally be submitted by email to June Thompson: d.j.thompson@ hull.ac.uk.

\section{Manuscript requirements}

1. Papers should not exceed 8000 words and should be preceded by an abstract of approximately 300 words and up to six key words of the author's choice. The first page of the manuscript should give the title, the name(s) and full mailing address(es) of the author(s), including e-mail addresses.

2. All relevant files, carefully labelled, should be sent electronically. Any graphics and screen dumps must be provided as separate files from the text (e.g. as .jpg or .tif files). Please indicate which graphics package you have used to produce them. Text should be in Word and not in any other word-processor or DTP formats. Do not embed graphics within a word processed document.

3. Text should be left-aligned only, double spaced throughout, with wide margins. Sheets should be numbered consecutively.

4. It is the responsibility of authors to provide written permission for the reproduction of any graphic or screen-shots included with the paper. It is also the responsibility of authors to check the accuracy of URLs cited within articles or references at the time of submission.

\section{Conventions}

Spelling: British or American English spelling may be used provided it is used consistently throughout the paper.

Footnotes should be kept to a minimum. Any acknowledgements, or explanation of the genesis of an article, should appear as the first note keyed to the article title by an asterisk (*). Note indicators in the text should follow punctuation.

Sub-headings should be typed with prefatory numbers indicating the level of importance, 1, 1.1, 1.1.1. No more than three levels of subheading should normally be used.

Abbreviations. Do not use fullstops in abbreviations: ICI, OBE not I.C.I., O.B.E. When referring to the title of an organisation by its initials, first spell out the title in full followed by the abbreviation in brackets, thus: Imperial Chemical Industries (ICI). Thereafter refer to ICI.

Underlining. Do not underline. Use italics or bold for emphasis.

Bibliographical references should be given in parentheses in standard author-date form in the body of the text: (Davies 1995:65). When a second or subsequent work by a particular author in the same year is cited, references should be distinguished by letters (a, b, c, etc.) placed after the date. When a work is written by three or more authors, all names should be given in the first citation: (Eck, Legenhausen \& Wolff 1995). In subsequent citations, the first name only should be given with et al. added. A complete list of references cited should be typed double-spaced at the end of the article, using the following conventions:

i. Single-author books

Davies, G. D. (1985) Talking BASIC: an introduction to BASIC programming for users of language. Eastbourne: Cassell.

ii. Dual-author books

Davies, G. D. and Higgins, J. J. (1985) Using computers in language learning: a teacher's guide. London: CILT.

iii. Multiple-author books

Eck, A., Legenhausen, L. and Wolff, D. (1995) Telekommunikation im Fremdsprachenunterricht. Bochum: AKS-Verlag.

iv. Edited books

Rüschoff, B. and Wolff, D. (eds.) (1996) Technology-enhanced language learning in theory and practice: EUROCALL 94: Proceedings. Szombathely: Berzsenyi Dániel College.

v. Articles in journals, magazines, etc.

Little, D. (1994) Learner autonomy: a theoretical construct and its practical application. Die neueren Sprachen, 93 (5): $430-442$.

vi. Articles in books

Johns, T. (1991) Data-driven learning and the revival of grammar. In: Savolainen, H. and Telenius, J. (eds.), EUROCALL 91: Proceedings. Helsinki: Helsinki School of Economics, 12-22.

vii. Websites

If you wish to refer to a URL, either within your text or as a reference, do not include 'URL' or any additional punctuation, e.g. http://www.eurocall.org

\section{Proofreading}

First proofs may be read and corrected by contributors provided that they can guarantee to return the corrected proofs within four days of receipt. Contributors should correct printers' errors but not introduce new or different material at this stage.

\section{Offprints}

In lieu of offprints, contributors will be provided with one copy of the printed issue in which their paper is published, free of charge, together with a PDF file of their paper.

This journal issue has been printed on FSC-certified paper and cover board. FSC is an independent, non-governmental, not-for-profit organization established to promote the responsible management of the world's forests. Please see www.fsc.org for information. 


\section{CAMBRIDGE}

\section{JOURNALS}

Annual Review of Applied Linguistics

Volume $29 \quad 2009$

Language Policy and

Language Assessment

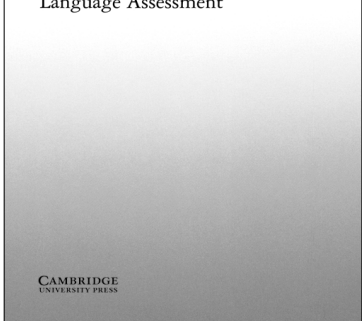

\section{Annual Review of Applied} Linguistics

is available online at:

http://journals.cambridge.org/ap/

To subscribe contact

Customer Services

in Cambridge:

Phone +44 (0)1223 326070

$\mathrm{Fax}+44(0) 1223325150$

Email journals@cambridge.org

in New York:

Phone +1 (845) 3537500

Fax +1 (845) 3534141

Email

subscriptions_newyork@cambridge.org

\section{Annual Review of Applied Linguistics}

\section{Editor-in-Chief}

Mary McGroarty, Northern Arizona University, USA

Annual Review of Applied Linguistics reviews research in key areas in the broad field of applied linguistics. Each issue is thematic, covering the topic by means of critical summaries, overviews and bibliographic citations. Every fourth or fifth issue surveys applied linguistics broadly, offering timely essays on language learning and pedagogy, discourse analysis, teaching innovations, second language acquisition, computer-assisted instruction, language use in professional contexts, sociolinguistics, language policy, and language assessment, to name just a few of the areas reviewed. It provides over 500 new citations each year.

\section{Price information is available at:} http://journals.cambridge.org/apl

\section{Free email alerts}

Keep up-to-date with new material - sign up at http://journals.cambridge.org/alerts 


\section{CAMBRIDGE}

\section{JOURNALS}

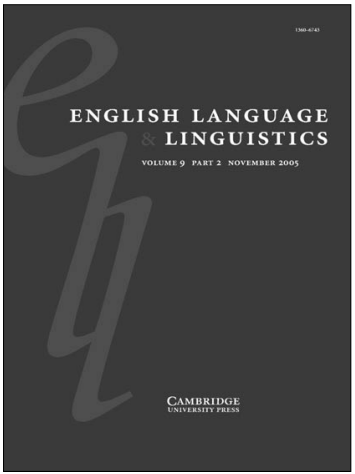

English Language and Linguistics is available online at:

http://journals.cambridge.org/ell

To subscribe contact

Customer Services

in Cambridge:

Phone +44 (0)1223 326070

Fax +44 (0)1223 325150

Email journals@cambridge.org

in New York:

Phone +1 (845) 3537500

Fax +1 (845) 3534141

Email

subscriptions_newyork@cambridge.org

\section{English Language \& Linguistics}

\section{Editors}

Bas Aarts, University College London, UK

David Denison, University of Manchester, UK April McMahon, University of Edinburgh, UK

English Language and Linguistics focuses on the description of the English language within the framework of contemporary linguistics. The journal is concerned equally with the synchronic and the diachronic aspects of English language studies. Articles contribute to our understanding of the structure and development of the English language.

Price information is available at: http://journals.cambridge.org/ell

Free email alerts

Keep up-to-date with new material - sign up at http://journals.cambridge.org/alerts 


\section{CAMBRIDGE JULNALS}

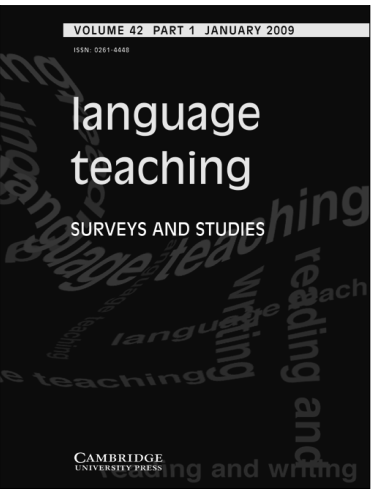

\section{Language Teaching}

is available online at:

http://journals.cambridge.org//ta

To subscribe contact Customer Services

in Cambridge:

Phone +44 (0)1223 326070

Fax $+44(0) 1223325150$

Email journals@cambridge.org

\section{in New York:}

Phone +1 (845) 3537500

Fax +1 (845) 3534141

Email

subscriptions_newyork@cambridge.org

\section{language teaching}

\author{
SURVEYS AND STUDIES
}

\section{Editors}

Ewa Jaworska, University of Essex, UK

Graeme Porte, University of Granada, Spain

Language Teaching provides a convenient source of references on current research in second and foreign language learning and teaching. Each issue offers at least one specially commissioned state-of-the-art article on a specific topic. A new series of articles provides an overview of second language acquisition and teaching research in individual countries, while another series reviews research into the teaching of languages other than English. Each volume includes about eight hundred abstracts of recent research articles on areas including reading and writing, teacher education, testing, bilingualism and neurolinguistics, selected from key international periodicals.

\section{Price information is available at: http://journals.cambridge.org/lta}
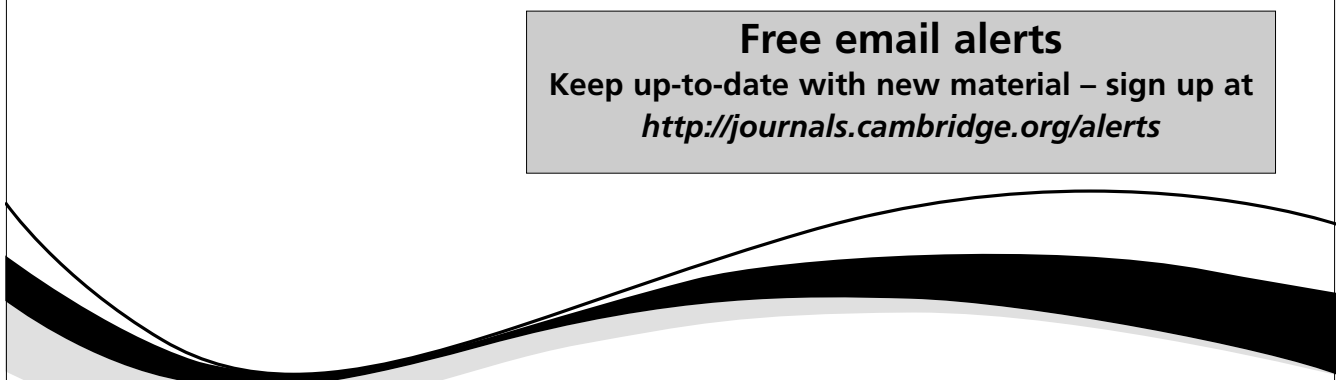


\section{CAMBRIDGE JOUNALS}

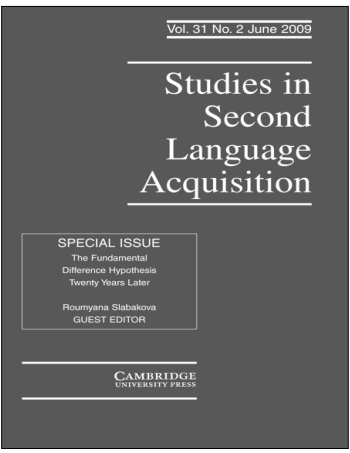

Studies in Second Language Acquisition

is available online at:

http://journals. cambridge.org/sla

To subscribe contact

Customer Services

in Cambridge:

Phone +44 (0)1223 326070

Fax $+44(0) 1223325150$

Email journals@cambridge.org

in New York:

Phone +1 (845) 3537500

Fax +1 (845) 3534141

Email

subscriptions_newyork@cambridge.org

\section{Studies in \\ Second \\ Language \\ Acquisition}

\section{Editor}

Albert Valdman, Indiana University, USA

\section{Associate Editor}

Susan Gass, Michigan State University, USA

Studies in Second Language Acquisition is devoted to the scientific discussion of issues in second and foreign language acquisition of any language. Each volume contains four issues, one of which is generally devoted to a current topic; the other three contain articles and reports of quantitative and qualitative empirical research.

\section{Price information is available at: http://journals.cambridge.org/sla}

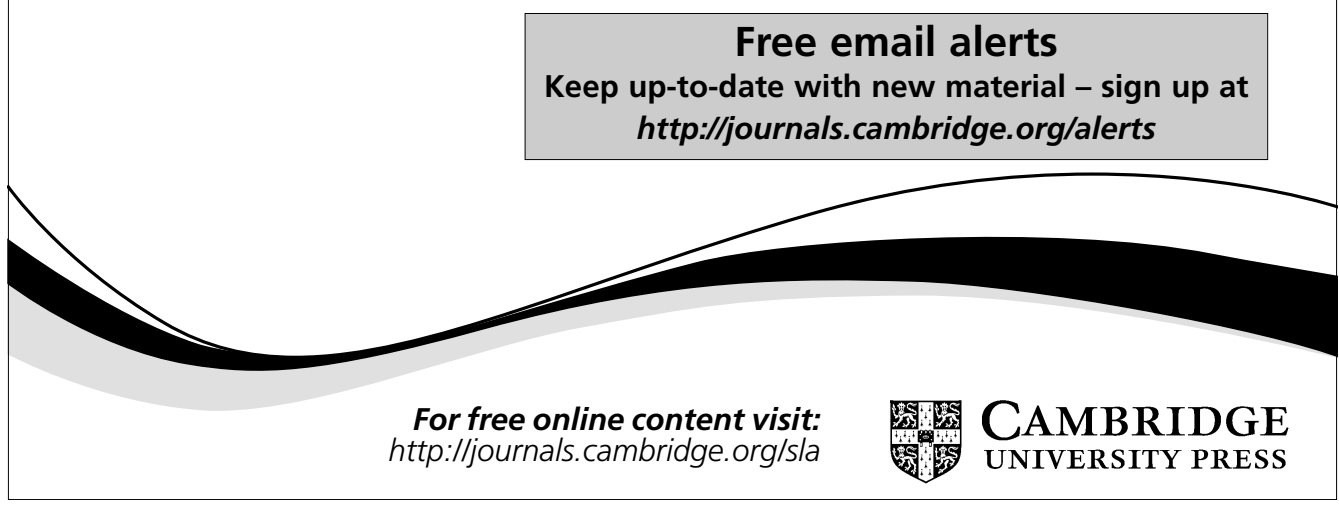

